喘息合併重症肺結核の外科的療法

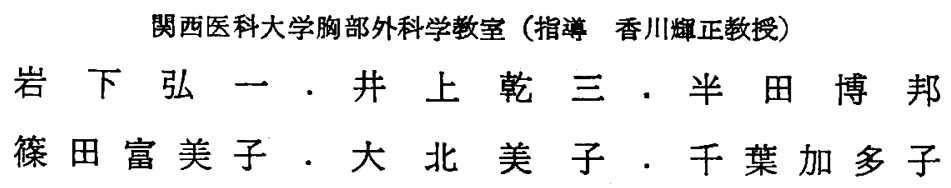

昭和31年 4 月以降，私達の教室飞おいても重症肺結核 の外科的療法に関して一連の実験的並びて臨床的研究を 続けてきたが，今回は特飞喘息合併重症肺結核の外科的 療法飞就いて検討し, 若干の知見を得たので報告する.

重症肺結核の外科的治療《関する手術の許容限界飞関 しては既に諸学者により数多くの研究, 発表が行われて いるが，なお，実地臨床上では残された問題む数少なし としない，その一つに最近注目され出した気管支喘息, 乃至喘息様気管支炎を合併した重症肺結核の外科的治療 の問題がある.

気管支喘息なる疾病は Hippocrates の昔より既飞知 られている疾病でありながら, 未だその確実なる治療法 のないままに今日飞至つている。しかし前世紀までは，

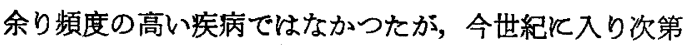
そその数を増し，殊に第二次大戦を境とし，日常生活の 煩雑化に伴うストレスの増強, 各種疾病に対する予防注 射の広䉐な利用, 抗生物質を含む化学療法の増加並び飞 都市の空気污染，室内塵の増加等によるためか，明らか そその数を堌している.

このような気管支喘息患者の增加に比例して, 肺結核 患者の中にすを，気管支喘息或いは喘息様症状を伴う あのが次第に増加の傾向を示している.

さて，かかる気管支喘息合併肺結核患者は，その多く が低肺機能例であつて最初から手術不適と見做されるか, 或いは外科医により敬遠され，化学療法のみ飞よつて治 療され勝ちである.しかもての種の患者は化学療法も比 較的飞奏効し難く遂には重症肺結核の状態にまで追込ん でしうような場合も少なくない，とのような喘息合併 肺結核患者の中飞は，結核発病前から既飞気管支喘息飞 䍜患している場合もあるが，その数は少なく比較的多い のは寧ろ結核発病後に起つてくる型のものである. かよ うな型のものは結核と気管支喘息乃至喘息様気管支炎が 悪循環的飞㗢くためか結核の病勢の進展伴ない喘息症 状も增悪してくるあのが多いように思われる。

なお，外科洖られてくるような症例は一般に肺機能 低下あ著明であり, 加うると菌耐性高度のものが多く,
肺切除術困難と見做される垐合も少なくない。 そとで私達はこのような気管支喘息合併肺結核患者の 外科的療法沉就き, 私達の経験した症例飞就いて報告し, 若干の考按を加えて見たいと思う。

\section{自 酫 例}

教室開設以来, 表 1 亿示すよう亿 6 名の喘息合併肺結 核患者飞手術を施行, 軽快 3 名, 不变 2 名, 増悪死亡 1 名の成績を得ている.

この中良好な経過をたどつた症例, 並びそ増悪死亡せ る症例就いてその詳細を報告する。

〔症例 1〕 K. F. 40才, 女.

結核発病後, 化学療法施行中気気管支喘息を併発し, 高度の心肺機能低下と耐性発現をきたしたが，空洞切開 術によつて，結核病巣の好転と同時に喘息症状の著明な 軽快を招来し得た 1 例である.

昭和28年 2 月頃感冒様症状を以て発病, X線診断过 り右肺浸潤を指摘され，自宅で SM.PAS の併用療法を 約 1 力年受けた後，29年12月本学内科六院した。 その 後もさらに化学療法を継続し外科転科してくるまで, SM $350 \mathrm{~g}$ ，カナマイシン $70 \mathrm{~g}$, その他 PAS, INH, PZA を連続して使用している。

な拓，約 3 年前の冬から喘息様咳濑発作を来たすよう になり最初は此較的軽微で冬季にのみ強い発作があつた が，2 年目頃から症状が激しくなり近頃では殆んど昼夜 を問わず呼吸促迫感と喘鳴飞悩まされている，但し，喀 痰量は 1 日 $20 \mathrm{cc}$ 前後, 食䓡は普通であるが睡眠は呼吸 困難のために障碍されており, 毎日午前 4 時頃, 息が詰 まる感じがあつて目が覚め, 起坐位をとるという.

結核発病までは，生来比較的健康な方で著患を知らす 家族歪は父および兄が肺結核で死亡している以外特記事 項はない. 入院時, 喀痰中菌は Gaffky 4 号, 赤沈 1 時間値 $37 \mathrm{~mm}, \mathrm{X}$ 線所見は図 1 火示す如く右銷骨下飞壁 の比較的万すい径 $3.8 \times 3.2 \mathrm{~cm}$ の大きい空洞とその周辺 の雲状陰影，その他左肺尖及び下野を主として殆んど全 肺野にわたり撒布巣を認め, 部分的には石灰化してい 
表 1 症例

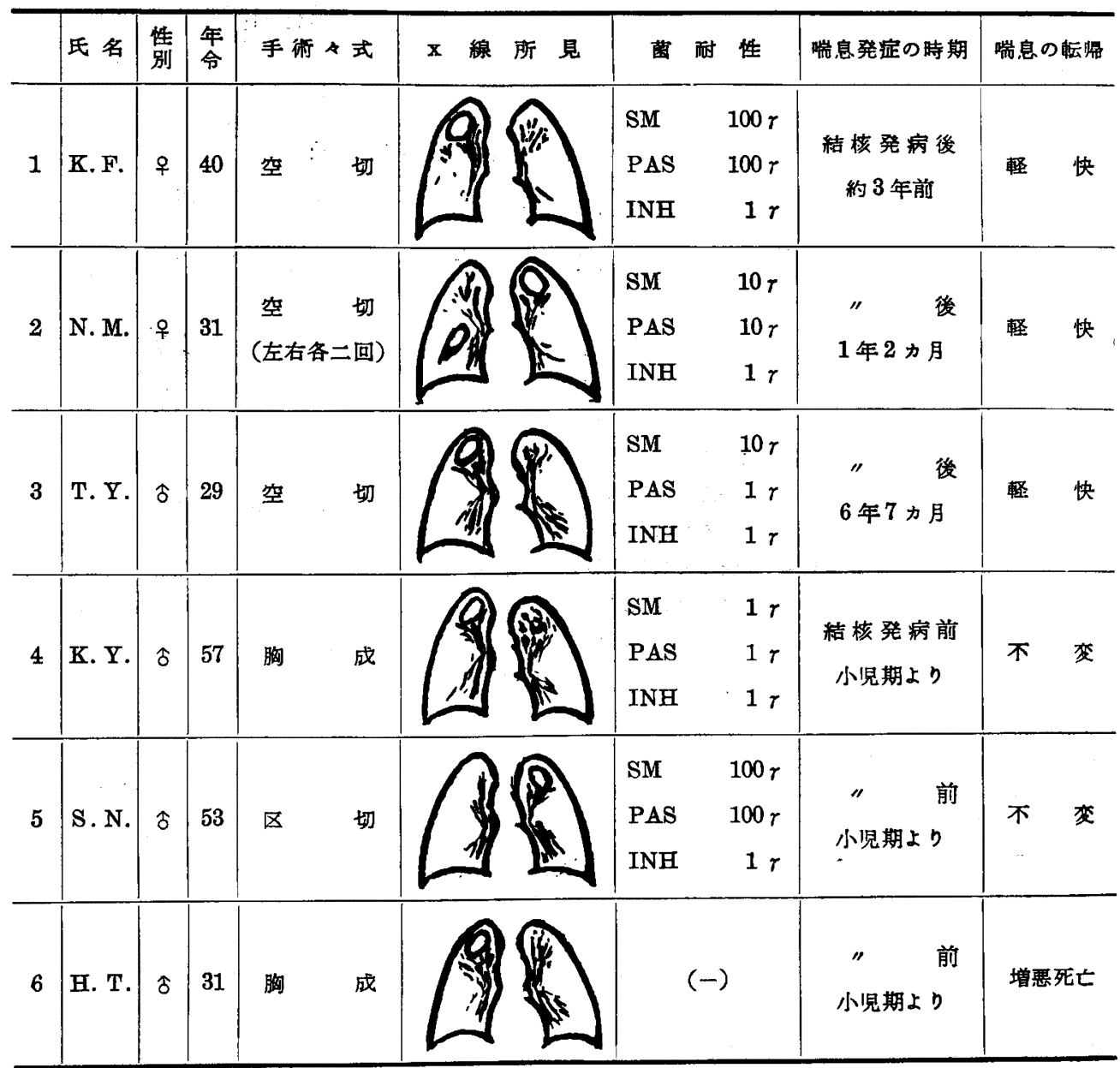

る.

理学的所見で殁んど全肺野に乾性, 湿性ラ音を聴取 する．喀痰中菌は SM $100 r$ 完全, INH $1 r$ 完全, PAS $1 r$ 不完全耐性があり，血液所見は，赤血球 350 万，

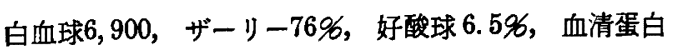
$7.4 \mathrm{~g} / \mathrm{dl}$ ，グロス反応1.5を示す.

術前の心肺機能検查成績恃表 2 のようK, 肺活量, 分 時最大換気量ともかなり著しく減少, 残気率の上界蝠 度であり, 換気能力の障碍が著しい, 肺動脈王は安静時 では，略々正常限界内にあるが，13\% $\mathrm{O}_{2}$ 負荷とより急 速且つ高度の上昇を招来している。

喘息症状, 低下した心肺機能飞加うると喀痰中菌の高 度耐性等の所見よりみて，この症例明らか飞肺切除術 飞䢔しないし，また街後に换気能力の減少を来大寸胸麻 成形術もさらに不道と考えられたが，術前種々の抗喘息
薬剂, IPPB のテストの結果, 強化麻醉 Cocktail 使用 とより喘息発作を略々扔さえ得る見通しを得たのて，残 された唯一の手段として空洞切開術を行うことにした。

34年10月26日手術施行，背部认空洞を開放し，術後 Viomyein を少量づつ連日空洞内撒布して処監を綕け たが，約 2 力月後洞腔は肉眼的飞殆んど净化された状態 となつたので脅肉弁を充填し，同時飞上部助骨を数 $\mathrm{cm}$ づつ短かく切除して督い虚脱を加えた。

然るK，空洞の開放処置後それまで極めて高度ておつ

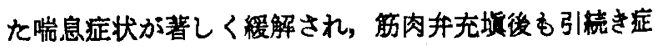
状の軽快をみて今日と至つている。喀痰中菌は術直後 一回のみ陽性てあった，以後塑抹培䓹共陰性化してい ろ.

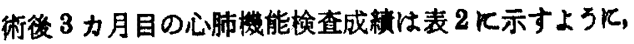

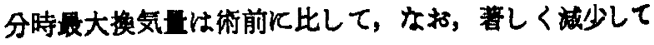




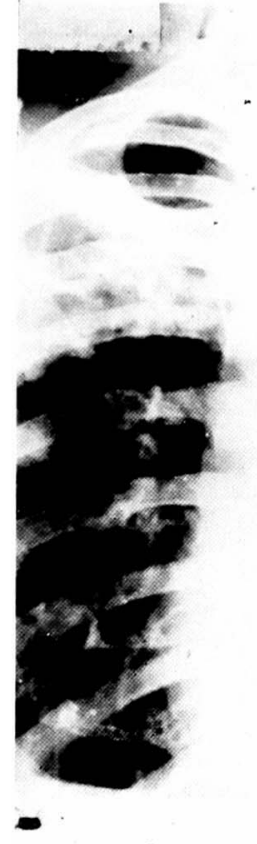

図 1 症例 1 の術前レントゲン像

表 2 症例 1 の心肺機能検査成績

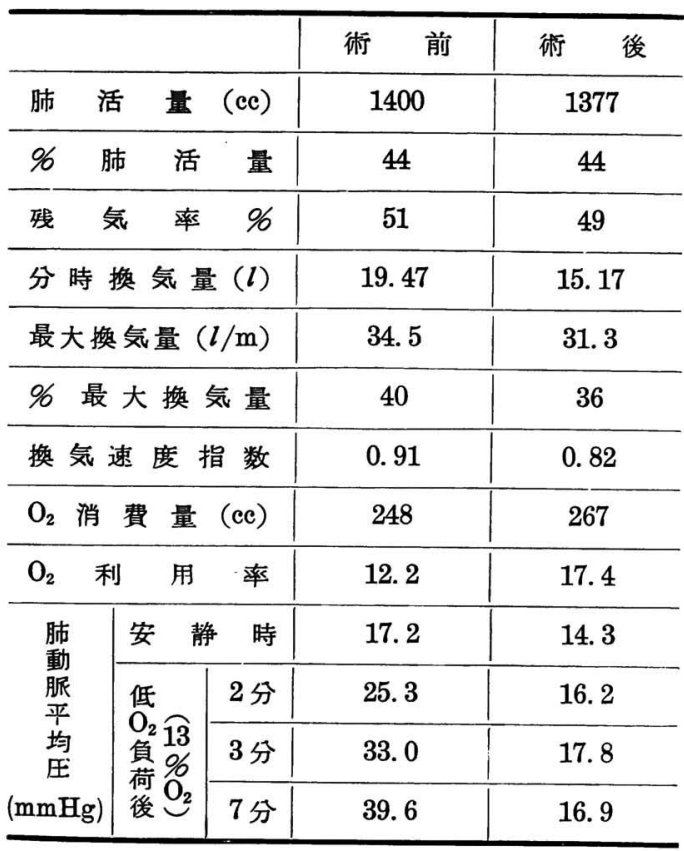

いるが，肺活量の減少は極めて怪徵であり酸素摄取率も 低いが術前に比べればやや上昇している. 特に肺動脈圧 は術前と同様の低酸素負荷を行つても著しい上昇を示さ
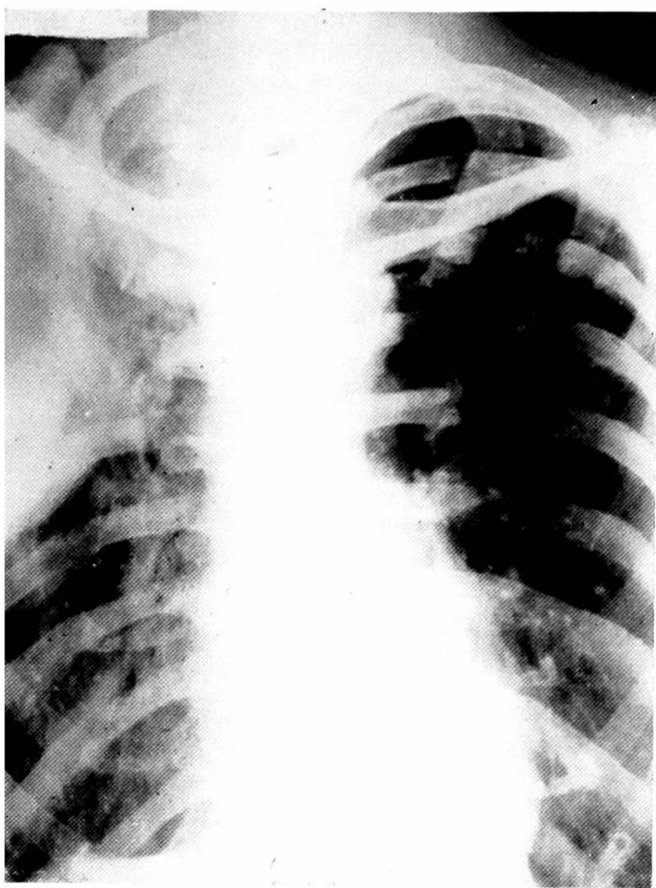

図 2 症例 1 の術後レントゲン像

なくなつている.

図 2 は術後 4 カ月の $\mathrm{x}$ 線所見である.

症例 2 N.M. 31才，女.

症例 1 と同様, 結核発病後に喘息を併発し, 両側空洞 切開術を繰り返し行つて治療軽快せしめ得たものである. 昭和29年10月頃，集団検診で右肺上野の浸潤巣を発見 され，自宅で約 1 力年 SM. PAS の併用療法を続けたと ころ, 陰影は縮小安定し, 培養も陰性化したので，一応 治瘾したものとして普通生活に戾つた.

しかるに約 2 力年後, 再び微熱喀痰等の症状あり, $\mathrm{X}$ 線撮影の結果左上野及び右下野に空洞を含む滲出性病单 の出現を指摘され，三者併用療法を再開し，2 2 クール続 行前後より喘息様咳嫩発作が頻発するようとなつた.

入院時, 喀痰中菌は, Gaffky 7 号, 赤沈 $62 \mathrm{~mm}$, 理 学的所見では両肺野とも乾性ラ音出没喘鳴も強い. X線 所見では図 3 と示すようと左銷骨下に径 $3.5 \times 2.8 \mathrm{~cm}$ の 辺縁不整な空洞と右肺門飞接近して $3 \times 2 \mathrm{~cm}$ 大の壁は うすいが硬化性と思われる空洞，その他略々全肺野飞亘 つて石灰化单を含む撒布巣を認めた.

入院後も引続き PZA, INH の併用を行つたが，胸部 所見，喘息症状ともに著変を認めず，排菌だけでも止め て欲しいという患者の切なる希望もあり手術を施行する ことに決定した。

術前の菌, 耐性検査では SM $100 r$ 完全, PAS $10 \gamma$ 


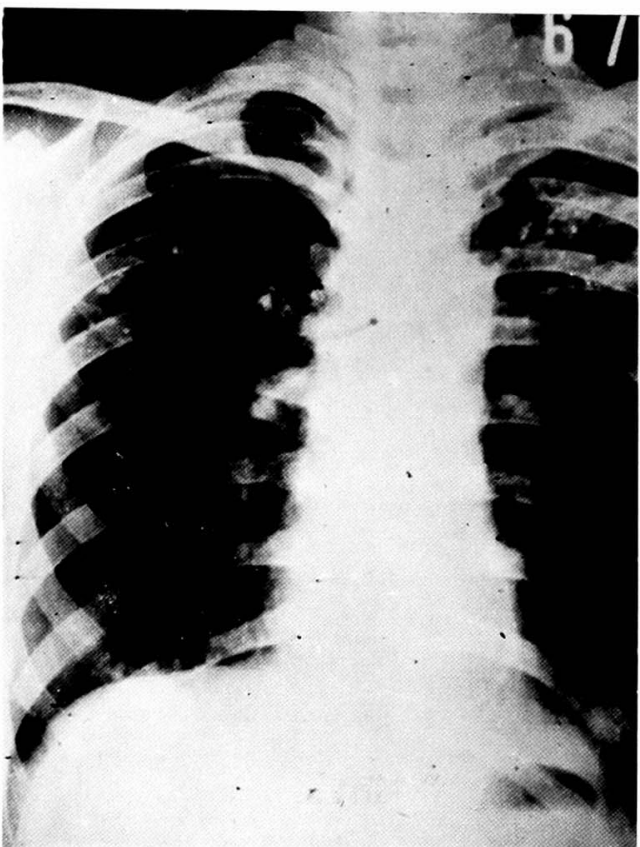

図 3 症例 2 の術前レントゲン像

不完全, INH $1 r$ 完全と各梖剂飞対して耐性がある. 肺活量は 2000 ecで，\% VCは 58, MBC は 52 であり, 手術施行の面より考光肺機能は比較的良好であるが，主 要病巣すなわち，空洞の位置，大きさより考えて見るに， 右下葉の空洞並びそ左上野飞空洞があるため，むしこれ を切除療法沉頼らんとするか，左上葉切除術及び右下葉 切除術を施行しなければならぬ。このことは菌の耐性, 肺機能及び喘息合併の面より考えて不可能と考えねばな Бぬ.

しかし患者の経験よりこの喘息発作はネオフィリン坐 薬により比較的寛解しているという事実もあり程々考虑 の末，躬余の一策として空洞切開術を行うことに決定し た.

昭和32年10月12日, 先づ左肺の空洞を切開々放し, 力 ナマイシン, INH 併用の下飞約 2 力月間開放, 創面飞 カナマイシン, INH を撒布しつつ絹帯交换を続け，空 洞壁の浄化を待ち筋肉弁を充塡した，な招この際，柽い 胸成術を加えた．図 4 はこの術後のX線写真である。続 いて 2 力月後, 右下集の空洞を切開, 空洞壁を提爪清浄 の後，カナマイシンを撒布して一次的飞縫維した。 術後 な打強力な化学療法を施行したが, 残念ながら菌は塗玬 で陽性と出てしまつた．何れの術侧の火敗ならんと䧄疾 の分離探取を行つて見ると，左们共陽性であつた。 そてで 3 力月後, 左侧空洞飞対して一次们再切閒筋弁

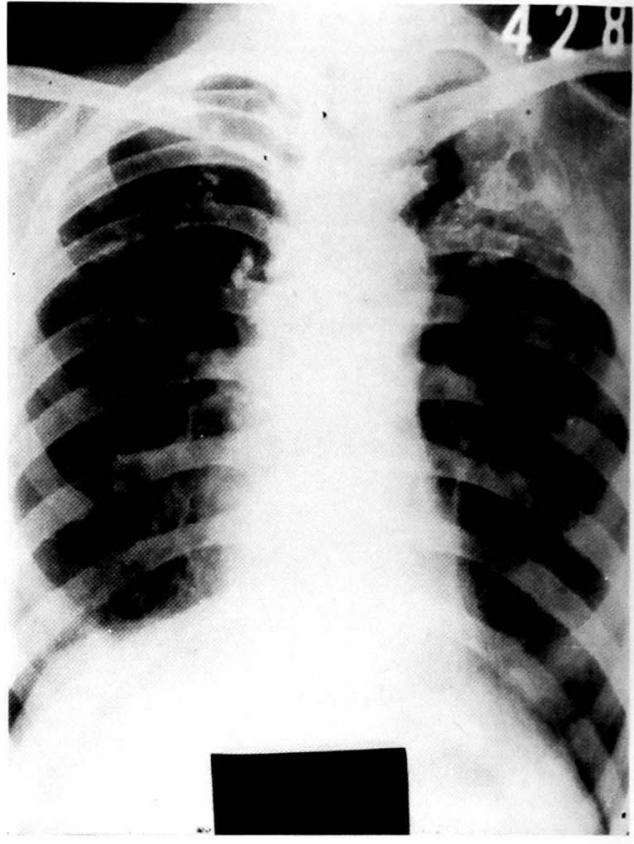

図 4 症例 2 の第 1 次左空切術後レ線像

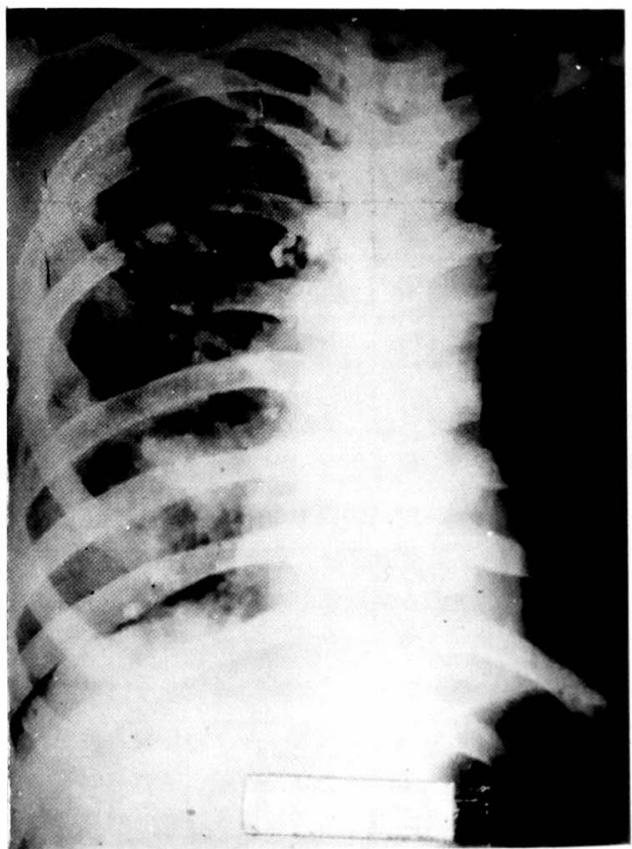

図 5 右第 1 次空切術後のレ線像

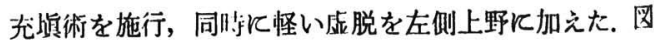
5 はこの術後のX線7 T真である。 さらに5 月後, 右肺 空洞飞対しても再切閒檤綰術を行つた。 


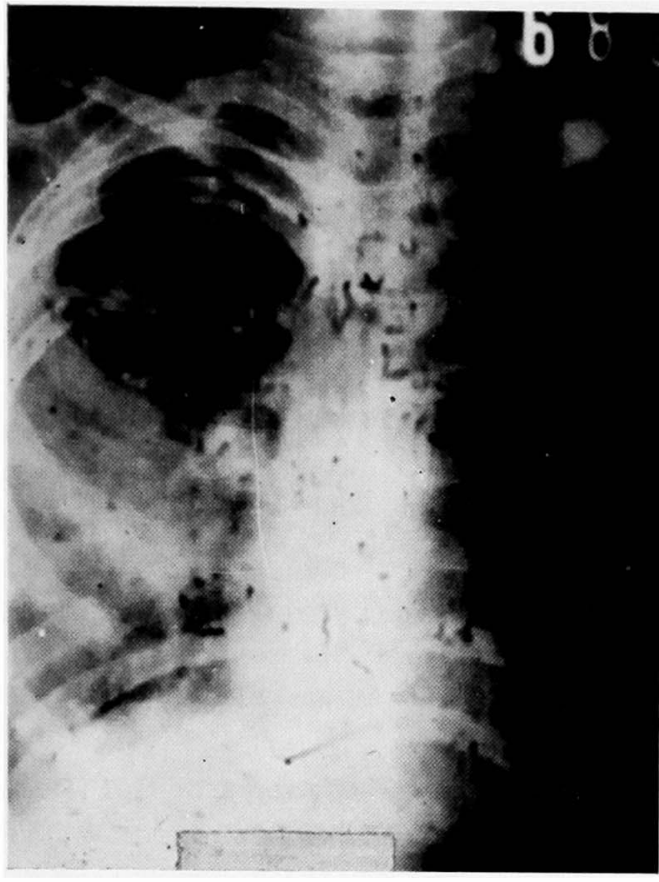

図6 左右再空切術後 1 ケ年のレ線像

術後，な招碩固飞微量排菌が続いたが，強力な化学療 法及び INH の気管内注入によりようやく菌の陰性化を 見, 最終手術より 1 年 4 カ月を経過している現在, 家庭 の主婦として元気、家事に従事している. な拓喘息発作 あ手術の経過飞従つて次第飞軽快，現在では殆んど咳濑 発作を認めなくなつている. 図 6 は術後 1 力年のレ線像 である.

症例 3 H. T. 31才, 男.

前 2 症例が比較的良好な経過をたどつたのに対し，本 症例は手術後, 喘息発作が増悪し, 不幸てして失つた症 例である。

喘息発作は幼時より存在し，成人するに及んでもなお， 年 1 2 回の大発作をみるという. 肺結核の発病は約 6 年前で数次にわたつて化学療法を続行したが菌陰性化せ す，入院時 X線所見では，上野に巨大空洞を含む乾酪单 及び左肺上野の撒布巣を認める. Gaffky 4 号, 赤沈平 均値 $42 \mathrm{~mm}$, 好酸球増多あり, 理学的所見で左右両肺野 飞乾性ラ音著明にして喘鳴む強い.

肺機能検查成績恃，\% $\%$ VC $48 ％$ MBC 45 , 残気率 49 と高度の肺機能低下を認めるが，結核菌の耐性は幸い として認められない。

以上の諸検查成績, 及び相当高度の喘息発作の存在よ り見て肺切除術不適と考兄, 右上野の病巢飞対して胸廓 成形術を施行した。 ところが術後 1 週間として強度の喘
息発作の発現をきたし，コーチゾンの使用により一時的 飞軽快を見たが，術後の微量排菌が継続し，且つ喘息発 作次第江頻発強度となり, 術後約 1 年, 強度の喘息発作 及び右心負荷増強により遂に不幸にして死の転機をたど つたのである.

\section{綜括並ひに考按}

以上，私達の教室で経験せる喘息合併重症肺結核患者 の手術治験例及び不成功例飞就いて簡単飞説明してきた が，以下これ等関する問題飞就き若千の考察を加えて 見たいと思う。

一般に肺結核発病後には典型的な喘息の発症は比較的 稀であるといわれている. すなわち，Turban, Meisser とよると $0.5 \%$, Gali Geze は $0.8 \%$, 滝野, 井沢は 0.3 \%と報告している．私達の教室の結核患者は凡て外科療 法を施行した患者許りであるのでさらにとの頻度は低く

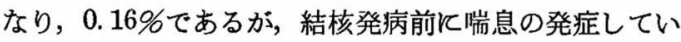
る場合も合わせると $0.3 \%$ となる.

何れとしてもいわゆる肺結核の軽症及び中等症の外科 療法の対象と考兄られた症例性各施設であらかた手術し つくされ，現在われわれの取扱つている症例は，その多 くがいわゆる重症乃至切除療法の対象とならないような 最重症結核である。もちろん，喘息合併肺結核患者の中 飞は，切除可能と考えられる症例もある．和田等が昭和 33年行つた本邦各施設火問合わせたアンケートルよると 気管支喘息合併者飞対しては, 肺結核切除療法は行わな い方針であるとするあのが多く，行うとするすのは13\% そすぎないと報告している.

われわれの教室に扔いても切除可能と考兄られる症例 飞は切除療法を施行するとやぶさかでなくまた切除療 法こそ肺結核の外科療法中の最良な方法であるという立 場をとるすのであるが，症例報告であ示したように，全 身所見, 病巣の解剖学的位置, 心肺機能検查成績, 菌耐 性及び合併症等より考学, 如何にしても切除不能な場合 あある.すなわち全身所見悪しく，菌耐性高度であり また重篤な合併症を有する者は切除の対象と考兄られな いのはもちろんである. 病棵の解剖学的位置飞関して も, 両側肺結核の中で切除施行飞より残存肺の機能も著 しく障碍されると考えられる場合も切除不適であるとす る.

さらと重要なととは各種心肺機能の検査成績である. Gaensler, Hueck, 佐川, 鈴木, 武田, 平野等飞より切 除の安全圈, 比較的安全圈, 危険圈の大体の限界は示さ れているのである. すなわち，一般に\%肺活量60以上を 安全圈，40 60\%を比較的安全圈，40以下を危険圈と見 
做されている，われわれも同様の考克と立ち，40 60\% のものKはさらに各種心肺機能検查特飞心力テ所見, 各 種負荷試験飞より切除の適，不適を決定して抢る.

気管支喘息の重症度の判定は, Hurtado そよると残 気率をむつてその重症度の判定をすへしとしているか Donard Kよると, 既飞肺気腫高度の気管支喘息では肺 内ガス混合が不良である点より考党，残気率の算定その あのにな括疑義があり，むしろ分時最大換気量の測定の 方が肺気腫の有無, その程度の判定に有利であるとして いる. もちろん喘息発作時, MBC の測定はその意味が 少なくまた測定不能の場合もあるが，Baldwin 及び Beale 等飞よると, 非発作時でも MBC はかなり減少し ているという報告むあるので，われわれは MBC をあつ て気管支喘息合併肺結核患者の重要な指標と考元ている のである.

さて以上の諸検查成績により，切除療法は不可能であ り，また本格的な胸成術の施行はその心肺機能面よりみ

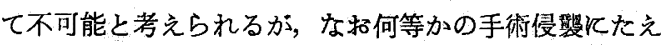
られるであろうと予測され，且つどうにかして排菌をと めて欲しいと切望するこの種の患者飞施行する何等かの 方法はないあのであろろか。ここに扔いてわれわれは長 石, 寺松らとより創始完成された空洞切開術の意義を見 出すむのである.

一般飞ての種の患者は，今まではただ慢然と無効な化 学療法のみに頼り勝ちであり，さらに結核の悪化飞歩調 を合わせて肺気腫も昂進し遂飞慢性の肺性心となり，不 幸な転帰をとる場合が多いのである。あちろんてのよう な不可逆性の病変高度な場合は手術不適と考学られるの であるが，このような状態立ち至るまでそ，適切な時 期汇何等かの手段を講じてとれ等進行性病変を停止する 必要があると考学るのである.

あちろん気管支㟨息の原因についても，逃走神経の緊 張六進によるとする Eppinger 説や，Walker 等のい 3 Allergie 説, 滝野のい弓肺迷走神経緊張艺進説等市 り，その療法にしても内科的或い外科的療法のいずれ を問わず，枚挙炕ととない程存在するが，いずれす末 だ対症療法の域を脱せずその根本的解決法はないようで ある。

すでと肺気腫高度となつた患者に対する外科的手術と 乙ては, Abbot, Crenshau, Wilson, Brown, Brock, Rockey，Mayer 等の術式が存在するのであるが，こ れ等は気管支喘息, 或いは肺気腫単独の手術であり, 肺 結核を合併している場合には，その趣きを異にするのは 当然である. 勿論気管支喘息飞対して内科的潦法無效な 場合飞は，喘息江対する外科的療法法，仮令その発作宽
解期間が短かく，一時的な効果しか見られなくても，ゃ

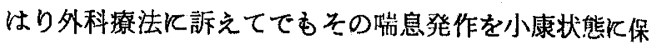
ち，結核に対する外科の遂行を計るのも一方法であるか， われわれの教室の症例は幸い，抗喘息薬剂飞比較的上く 反応したのでかかる外科手段化訴る必要はなかつたの である.

何れにしても，功るる気管支颛息合併重症肺結核患者 の外科的療法飞当つては, 次のような点より考兄, 空洞 切開術が最良な術式であると考えるのである。すなわ

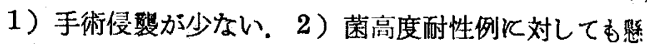
念なく施行出来る．3）空洞の開放処置飞より重症肺結 核汇随伴する中毒症状を緩解し得る，4）手術失敗例次 しても少ない手術侵警で反覆施行し得る。な扔肺気腫の 相当高度な場合には軽い虚脱を加えることにより心肺機 能の改善を期待し得る。

\section{結語}

気管支喘息合併肺結核患者飞は今まで比較的外科潦法 の対象外と考えられ放置される場合が多かつたのである が，私達は自家治験例を中心として，その臨休経験及び その手術術式飞就いて報告し, 同時飞多少の文献的考察 を加えて報告した。 な斿, かかる症例飞対して長石, 寺 松等の空洞切開術が最適の手術々式であるととを强調し た.

（本就交の要旨は第 3 回胸部外科学会関四地方会飞拧 いてシンボシシウムとして発表した.）

\section{参考文 献}

1) Abbot, O. A., et al : Tr. Nat. Tubereul. Assn. : 359,1952

2) Baldwin : Am. J. Med., 8, 701, 1947.

3) Beale, et al. : J. Allergy, 23, 1, 1952.

4) Crenshaw, G. L. et al. : J. Thorac. Surg., 24, 398, 1952.

5) Eppinger : Ztsch. F. Klin. Med., 67, 345, 1907.

6) Gaensler. E. A., et al : g. Th. Surg., 29, 163, 1955.

7) Gali Geze : Reg. S. Zentralbl. g. d. g. tbe. Forsch, $22,1919$.

8) Hueck, O. E., Zöllner N. : Thoraxchir, Bd. 2,421, 1955.

9) Hurtado. G ; clin. Invest., 13, 1027, 1934.

10) 平野政夫 : 京大結研紀要. $7: 54,1959$.

11）佐川弥之助，他：結核研究の進少. $16,9,1956$.

12) 佐川弥之助, 他 : 呼吸器祄療. $12,489,1957$.

13）铃木千贺志：日本医事新報. $1748,3,1957$.

14）武田義章：日外会誌. $54,196,1953$.

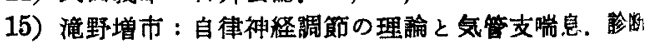
と治療社, 1957.

16) Turban, Meisser ; Z. f. Thk. Bd26, H. 1.

17）和田寿郎，他：日本胸部臨床。19,276,1960. 


\title{
On the Surgical Treatment of the Far-advanced Tuberculosis accompanied with Bronchial Asthma
}

\author{
Hirokazu Iwashita, Kenzo Inoue, Hirokuni Handa, \\ Fumiko Shinoda, Yoshiko Okita \& Katako Chiba
}

Dept. of Thoracic Surgery (Supervised by Prof. T. Kagawa, M. D.)

\section{Kansai Medical School}

The patient of the far-advanced pulmonary tuberculosis accampanied with bronchial asthma has been considered to be almostly impossible for the surgical treatment, and then been let alone.

We report the cases of these diseases who were successfully surgically treated, their clinical course and the modus of operation. We emphasize that cavernosotmy is most adequate modus of operation for these patients. 